\title{
Pengaruh Kualitas Produk dan Electronic Word of Mouth Terhadap Keputusan Pembelian Dimsum Mbeledos Surabaya
}

\author{
Dinda Dwi Ramadhani, Saino \\ Universitas Negeri Surabaya, Surabaya, Indonesia \\ Email corresponding author: ${ }^{1}$ dinda.17080324060@ mhhs.unesa.ac.id, ${ }^{2}$ saino@unesa.ac.id
}

\begin{abstract}
ABSTRAK
Supaya perusahaan dapat bertahan hidup dan bersaing diperlukan strategi pemasaran yang tepat yaitu dengan cara mempertahankan kualitas produk dan meningkatkan $E-W O M$ yang mudah mempengaruhi konsumen dalam mengambil keputusan pembelian. Penelitian ini bertujuan melihat bagaimana pengaruh kualitas suatu produk dan electronic word of mouth dalam mengambil keputusan pembelian. Penelitian ini merupakan penelitian deskriptif kuantitatif. Target demografis adalah pelanggan dimsum mbeledos, dan jumlah sampel 85 orang. Pengujian analisis regresi berganda yang digunakan mencakup uji analisis regresi, uji F, uji t dan koefisien determinasi. Penelitian ini memberikan hasil bahwa kualitas produk dan electronic word of mouth berpengaruh sangat besar pada keputusan pembelian. Hasil uji-t (parsial) kualitas produk dan electronic word of mouth memiliki pengaruh yang signifikan dan positif terhadap keputusan pembelian. Secara simultan Kualitas produk dan electronic word of mouth berkontribusi sebesar 57,3\% dan sisanya sebesar 42,7\% dipengaruh oleh variabel lain diluar penelitian ini.
\end{abstract}

Kata Kunci: Kualitas Produk, electronic word of mouth (E-WOM), Keputusan Pembelian

\section{PENDAHULUAN}

Industri makanan dan minuman meningkat pesat, terbukti pertumbuhan sekitar 9 persen pada tahun 2016. Industri makanan semakin beragam dalam menghidangkan jenis makanan. Perubahan tersebut disebabkan mengikuti gaya hidup masyarakat. Gaya hidup tersebut juga memberikan dampak pada pola konsumsi masyarakat. Pola masyarakat tertarik terhadap suatu makanan berbeda beda, pada sebagian hanya untuk memenuhi kebutuhan fisik mereka, sebagian lagi dijadkan hiburan.

Era mudahnya mencari informasi masyarakat menjadi lebih peduli terhadap apa yang akan mereka beli. Masyarakat akan mencari info lebih dalam mengenai apa yang dapat diberikan dari makanan tersebut. Masyarakat akan mencari tahu mengenai kualitas serta pendapat orang lain terhadap makanan tersebut. Sebab itu persaingan dalam bisnis tersebut semakin sulit, sehingga setiap pengusaha melakukan pemasaran yang efektif dan efisien agar memperoleh keuntungan besar, dan berdampak bagi kelangsungan sebuah restoran. Strategi yang dilakukan setiap restoran dimsum tersebut berbeda beda, dari harga yang lebih terjangkau, desain restoran yang "luxurious", model "all you can eat", nuansa China, dan berbagai macam. Strategi yang tepat merupakan dapat meningkatkan keputusan pembelian sehingga meningkatkan keuntungan sebesar-besarnya bagi restoran. Sesuai dengan pernyataan tersebut, menurut Kotler dan Keller (2013:22) menyatakan bahwa tiap perusahaan harus menjadi paling efektif dalam menciptakan maupun menyampaikan nilai pelangan kepada pasar yang ditentukan agar dapat memenangkan persaingan.

Untuk mengetahui strategi tersebut efektif atau tidak, maka penting untuk mengetahui keputusan pembelian tiap konsumen. Definisi keputusan pembelian menurut Kotler dan Keller $(2012,227)$ ialah tahap konsumen untuk menimbang tiap tiap pilihan hingga konsumen 
melakukan pembelian. Diawali dengan mengenali kebutuhan, lalu mencari informasi, mempertimbangkan tiap pilihan, pembelian, sampai dengan pasca pembelian.

Faktor yang dapat dipertimbangkan dalam mengelola restaurant agar bertahan adalah menjaga kualitas produk melalui kualitas rasa yang diberikan yakni harus selalu mengelola kualitas produk dengan baik melalui rasa produk atau tampilanya agar restoran dapat bertahan , dalam mengelola sebuah restauran agar bertahan adalah menjaga kualitas produk melalui kualitas rasa yang diberikan.

Kotler dalam Alma (2020) mengemukakan ialah sesuatu yang berfungsi sebagai pemuas kebutuhan dan keinginan konsumen. Senjata efisiensi untuk mengalahkan pesaing yaitu kualitas produk, seperti pendapat dari Lokman, dkk (2016) bahwa kualitas produk restoran unik dan bervariasi akan bertumbuh pesat dan berhasil dalam jangka panjang. Berpacu pada penelitian.

Selain kualitas produk yang mempengaruhi keputusan pembelian, $E$-WOM berpengaruh pula pada keputusan pembelian. E-WOM ialah pendapat atau konten dari pelanggan potensial maupun perusahaan mengenai produk tersebut. Pada zaman ini Electronic Word of Mouth sangat diperhatikan karena sangat mempengarruhi citra terhadap merk. Pada sisi calon konsumen, mencari detail tentang produk yang akan dibeli merupakan langkah untuk memastikan produk tersebut tepat untuk mereka. Jason Djimantoro, dan Vania Clairine Gunawan (2020) mendefinisikan E-WOM berpengaruh signifikan dan positif terhadap keputusan konsumen

Dimsum Mbledos Surabaya merupakan perusahaan dalam bidang makanan. Khususnya pada menu dimsum dalam bentuk siap saji. Berawal dari outlet di Surabaya tanggal 16 Agustus 2012. Menjual produk Dimsum siap saji maupun Frozen Dimsum. Dimsum Mbledos memiliki tagline "rasa bintang 5 dengan harga kaki 5". Telah memiliki 80 cabang, 1 outlet asli dan 79 outlet dengan sistem manajemen lepas (franchise).

Dimsum mbledos menjaga kualitas produknya dengan selalu menggunakan bahan yang baru setiap harinya, bahan berkualitas tanpa pengawet yang diperoleh dari kebun yang dikelola oleh manajemen Dimsum Mbledos. Dimsum Mbledos mendapatkan sertifikasi Halal dari (MUI) Majelis Ulama Indonesia, membuktikan kebersihan proses awal hingga produk siap saji maupun frozen food. Memiliki 40 varian menu yang diproduksi sendiri. Namun sering kali dimsum disajikan dalam keadaan sobek, yang dapat mengurangi keindahan nya, hal tersebut terjadi karena intensitas order yang tinggi. Menurut pendapat Dody Ridwan Yunianto (2016), yang dimana hasil penelitiannya yaitu variabel kualitas produk berpengaruh secara positif dan signifikan terhadap keputusan pembelian.Tetapi Rumondor, Dkk pada tahun 2017, menyatakan Kualitas Produk berpengaruh positif namun tidak secara signifikan $\mathrm{t}$ Dimsum Mbledos memiliki akun Instagram, yang mana informasi mengenai promosi gambar dari menu dimsum Mbledos diposting di tempat tersebut, tidak jarang calon konsumen berkomentar pada postingan, dan juga mengkaitkan akun Instagram kerabat mereka. Dimsum Mbledos mengatur tampilan postingan sedemikian rupa agar dapat terlihat menarik untuk dimakan. Pada beberapa momen, Dimsum Mbledos dalam beberapa promosi untuk meningkatkan aktifitas Electronic Word of Mouth, membuat diskon $20 \%$ dari harga normal hanya dengan melak ukan ulasan mengenai menu baru di akun Instagram mereka dan mengkaitkan pada akun instagram Dimsum Mbledos. Dari penelitian Chairul Akbar tahun (2018) berpendapat bahwa E-WOM berpengaruh terhadap keputusan pembelian, berbeda dengan pendapat Tommi dan Eristia (2014) E-WOM tidak memiliki pengaruh terhadap keputusan pembelian.

Kualitas produk dapat menarik calon konsumen agar tertarik suatu produk yang sedang ditawarkan perusahaan, calon konsumen akan membeli jika merasa tertarik dengan produk tersebut. Kotler dan Keller (2012) mendefinsikan kualitas produk ialah suatu produk berfungi sesuai maupun melebihi harapan konsumen. 
Kualitas produk dalam sebuah restoran dapat dibentuk melalui makanan, yang mana seluruh karakteristik makanan tersebut menjadi nilai harapan oleh konsumen. Dari pertimbangan kualitas produk konsumen akan menentukan pembelian produk tersebut.

Dari kajian teori terkait dengan kyalitas produk, maka indikator pengukuran Kualitas produk dikur dengan: (1) Freshness, Kesegaran makanan berhubungan dengan tekstur, rasa, dan aroma dari makanan itu sendiri. (2) Presentation, cara penyajian makanan pada konsumen untuk dapat dinikmati dan memberikan nilai yang positif harus menggunakan komposisi yang sudah diatur dan disesuaikan sesuai dengan yang sudah ditetapkan oleh perusahaan mulai dari tampilannya, tekstur ataupun rasa harus terlihat menarik,(3) Well Cooked, Makanan dimasak atau diolah dengan baik sehinga aman untuk dikonsumsi maupun menambah citarasa, (4) Variasi Menu, perusahaan harus memiliki keanekaragaman makanan, karena konsumen dapat terarik jika perusahaan memiliki berbagai macam varian yang ditawarkan. Berdasarkan teori dan peneliti terdahulu, sehingga dirumuskan hipotesis berikut:

\section{$\mathrm{H}_{1}=$ Kualitas Produk berpengaruh terhadap Keputusan pembelian}

WOM umumnya dilakukan bersama teman atau pun kerabat dekat mengenai produk. Ini terjadi sebab manusia merupakan makhluk sosial, yang jika menyukai suatu produk akan membicarakannya terhadap lingkungan sekelilingnya. Namun seiring peningkatan teknologi, manusia berkomunikasi tanpa tatap muka dan juga dapat berkomunikasi dengan banyak orang sekaligus. Maka dari itu timbul teknik pembaharuan dari WOM, yaitu E-WOM.

$E-W O M$ yaitu pendapat suatu produk dari seseorang secara positif atau negatife yang dilakuakan didalam sebuah internet. $E$-WOM tanpa disadari atau tidak, dapat terjadi begitu saja meskipun tidak ada niat untuk melakukannya. E-WOM dapat disebut sebuah komunikasi antar calon konsumen, perusahaan, dan juga pelanggan.

Berbeda dengan $E$-WOM yang dilakukan oleh lingkungan dekat tetapi juga dilakukan oleh orang tidak kita kenal sekalipun. E-WOM membutuhkan nilai kredibilitas yang cukup tinggi sehingga konsumen percaya. E-WOM memiliki banyak dampak baik bagi perusahaan salah satunya citra perusahaan. Citra baik dapat timbul melalui sebuah komunikasi E-WOM yang positif, sehingga konsumen lebih yakin mengenai produk yang akan dibeli. Dari kajian teori terkait dengan $E$-WOM, maka indikator pengukuran $E$-WOM dikur dengan; (1) Keahlian pengirim, Keahlian pengirim mengacu pada kredibilitas orang tersebut pada industri makanan. (2) Valensi pendapat, rekomendasi dari konsumen lain membuat konsumen tertarik untuk melakukan pembelian suatu produk (3) Konten, berupa suatu informasi yang tentang kualitas produk, harga yang ditawarkan, kebersihan, kenyamanan pada restaurant dan varian makanan ditawarkan. Berdasarkan teori diatas, maka dirumuskan hipotesis sebagai berikut:

\section{H2 = Electronic word of mouth berpengaruh terhadap Keputusan Pembelian}

Kotler (2017:17) Keputusan pembelian adalah keputusan yang mengarah terhadap penentuan pembelian sebuah produk. Keputuan pembelian terjadi dapat dipengaruhi oleh beberapa rangsangan dan juga pola perilaku pelanggan tersebut. Dalam persaingan bisnis perusahaan berusaha semaksimal mungkin menciptakan peningkatkan keputusan pembelian. Jika mengetahui alasan konsumen memilih produk maka aka menjadi sebuah keunggulan strategi untuk peningkatan penjualan produk tersebut.

Dari kajian teori terkait dengan keputusan pembeian, maka indikator pengukuran keputusan pembelian dikur dengan (1) Pilihan menu, (2) Frekuensi Pembelian, (3) Pola jumlah pembelian, dan (4) Metode Pembayaran. Berdasarkan teori diatas dapat dirumuskan hipotesis yaitu:

H3 = Kualitas Produk dan E-WOM secara simultan berpengaruh terhadap Keputusan Pembelian 


\section{METODE PENELITIAN}

Penelitian ini merupakan peneletian deskriptif kuantitatif. Kriterian populasi ialah pelanggan Dimsum Mbledos Surabaya cabang Merr, Jawa Timur. Sesuai dengan teori Hair, yaitu merekomendasikan jumlah sampel yaitu $5 \mathrm{x}$ jumlah item pertanyaan, maka sampel penelitian ini berjumlah $5 \times 17=85$ sampel dengan tingkat kesalahan 5\%. Sampel diambil dengan teknik random sampling. Diukur menggunakan skala likert sebagai pedoman untuk mengajukan pertanyaan atau pernyataan.

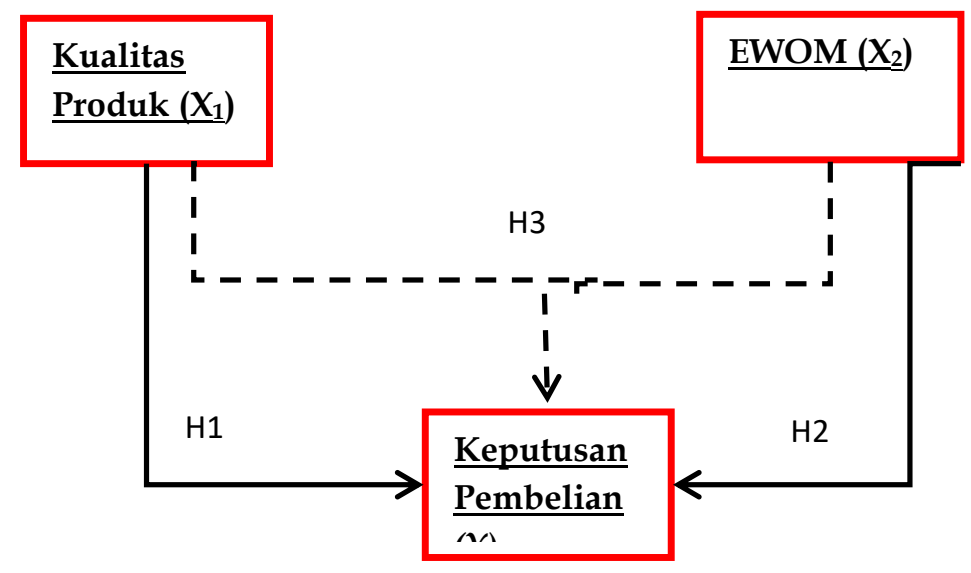

Gambar 1. Rancangan Penelitian

(Sumber : Diolah oleh penulis, 2021)

Data dikumpulakan dengan menyebar angket online dalam google form dengan link (https://forms.gle/7j6Ug21xEDja1eQ86).

Teknik analisis data yang digunakan ialah: uji validitas, reliabilitas, dan uji asumsi klasik yaitu normalitas, multikolinieritas serta heteroskedatisitas, untuk menguji data yang diperoleh memenuhi standar untuk melakukan regresi berganda. Lalu mengunakan regresi berganda untuk menganalisis hubungan variabel.

Uji validitas dilakukan pada 30 responden guna mengukur valid atau tidaknya setiap instrumen pernyataan dalam angket.

Tabel 1 Validitas

\begin{tabular}{ccccc} 
Pernyataan & r hitung & Nilai.Sig & A & Keterangan \\
\hline \hline 1 & $.612^{* *}$ &, 000 & 0,05 & Valid \\
2 & $.712^{* *}$ &, 000 & 0,05 & Valid \\
3 & $.682^{* *}$ &, 000 & 0,05 & Valid \\
4 & $.572^{* *}$ &, 000 & 0,05 & Valid \\
5 & $.637^{* *}$ &, 000 & 0,05 & Valid \\
6 & $.436^{* *}$ &, 000 & 0,05 & Valid \\
7 & $.500^{* *}$ &, 000 & 0,05 & Valid \\
8 & $.554^{* *}$ &, 000 & 0,05 & Valid \\
9 & $.700^{* *}$ &, 000 & 0,05 & Valid \\
10 & $.778^{* *}$ &, 000 & 0,05 & Valid \\
11 & $.871^{* *}$ &, 000 & 0,05 & Valid
\end{tabular}




\begin{tabular}{lllll}
12 & $.767^{* *}$ &, 000 & 0,05 & Valid \\
13 & $.758^{* *}$ &, 000 & 0,05 & Valid \\
14 & $.661^{* *}$ &, 000 & 0,05 & Valid \\
15 & $.557^{* *}$ &, 000 & 0,05 & Valid \\
16 & $.764^{* *}$ &, 000 & 0,05 & Valid \\
17 & $.606^{* *}$ &, 000 & 0,05 & Valid \\
\multicolumn{4}{c}{ (Sumber :Diolah peneliti, 2021) }
\end{tabular}

Dilihat dari tabel diatas nilai r-hitung $>0,30$ dan tingkat signifikansi pada setiap pernyatan memiliki nilai kurang dari 0,05 , sehingga setiap pernyataan dalam angket dinyatakan valid. Uji reliabilitas ini dilakukan pada 30 responden guna mengukur apakah item dalam pernyataan dapat dipercaya.

Tabel 2 Reliabilitas

\section{Variabel Tingkat Signifikasi Nilai Cronbach's Alpha Keterangan}

\begin{tabular}{llll}
\hline \hline Kualitas Produk & 0,6 &, 691 & Reliabel \\
Electronic word of mouth & 0,6 &, 794 & Reliabel \\
Keputusan Pembelian & 0,6 &, 689 & Reliabel
\end{tabular}

(Sumber :Diolah peneliti, 2021)

Pada tabel diatas uji reliabilitas diatas dinyatakan bahwa semua item pertanyaan tiap variabel nilai Cronbach's Alpha $\geq 0,60$. Dapat dinyatakan data bersifat reliabel.

\section{HASIL DAN PEMBAHASAN}

Dari data yang sudah terkumpul, maka dapat didiskripsikan sebagai berikut.

\section{Karakteristik Responden}

85 responden dengan ciri-ciri berdasarkan gender, umur, pendapatan dan pekerjaan.

\section{Tabel 3 Responden}

\begin{tabular}{lrr} 
Kategori & Jumlah & Persentase \\
\hline \hline Gender & & \\
\hline Laki-Laki & 7 & 8,2 \\
Perempuan & 78 & 91,8 \\
\hline Usia & & \\
\hline $17-22$ & 3 & 3,5 \\
Tahun & & \\
$23-28$ & 78 & 91,8 \\
Tahun & & \\
29-34 & 4 & 4,7 \\
Tahun & & \\
\hline Pekerjaan & & \\
\hline
\end{tabular}




\begin{tabular}{lcc}
$\begin{array}{l}\text { Pelajar / } \\
\text { Mahasiswa }\end{array}$ & 2 & 2,4 \\
$\begin{array}{l}\text { Pegawai } \\
\text { Negeri }\end{array}$ & 23 & 27,1 \\
$\begin{array}{l}\text { Pegawai } \\
\text { Swasta }\end{array}$ & 60 & 70,6 \\
\hline Pendapatan & & \\
\hline < 1 Juta & 2,4 \\
$\begin{array}{l}\text { 1 Juta - } \\
\text { Juta } \\
\text { 3 Juta - 5 }\end{array}$ & 16 & 18,8 \\
Juta & 67 & 78,8 \\
\hline Jumlah Kunjungan & \\
\hline 1 Kali & 13 & 15,3 \\
2 Kali & 31 & 36,5 \\
3 Kali & 18 & 21,2 \\
>3 kali & 23 & 27,1
\end{tabular}

(Sumber :Diolah peneliti, 2021)

Responden terbanyak merupakan perempuan yaitu sebanyak 78 orang $(91.8 \%)$. Sedangkan pada kelompok usia antara 23-28 tahun merupakan kelompok yang memiliki persentase paling banyak dalam partisipasi pengisian angket penelitian. Pada dua kategori tersebut maka dapat ditarik kesimpulan bahwa pelanggan perempuan pada usia tersebut umumnya menyukai makanan asing seperti dimsum.

Responden dengan pekerjaan pegawai swasta merupakan mayoritas kelompok dengan jumlah 60 orang $(70.6 \%)$. Sedangkan mayoritas responden memiliki pendapatan $3-5$ juta sebesar 67 orang $(78.8 \%)$.

\section{Uji Asumsi Klasik}

\section{Uji Normalitas}

Tabel 4 Kolmogorov Smirnov Test

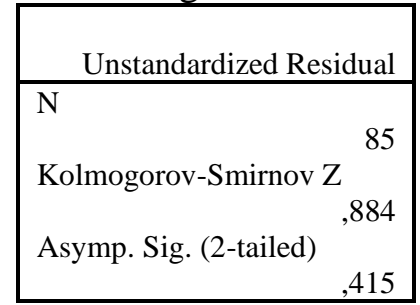

(Sumber :Diolah penelit, 2021)

Nilai sig $0,415 \leq 0,05$ artinya data berdistribusi secara normal.

\section{Uji Multikolinieritas}

Tabel 5 Multi Collinearity Test

Collinearity Statistics

\begin{tabular}{cc} 
Tolerance & VIF \\
\hline \hline, 543 & 1,842 \\
, 543 & 1,842
\end{tabular}

(Sumber :Diolah peneliti, 2021) 
Nilai tolerance $\geq 0,1$ dan nilai VIF $\leq 10$ maka data tidak mengalami kolinieritas ganda..

\section{Uji Heteroskedatisitas}

Scatterplot

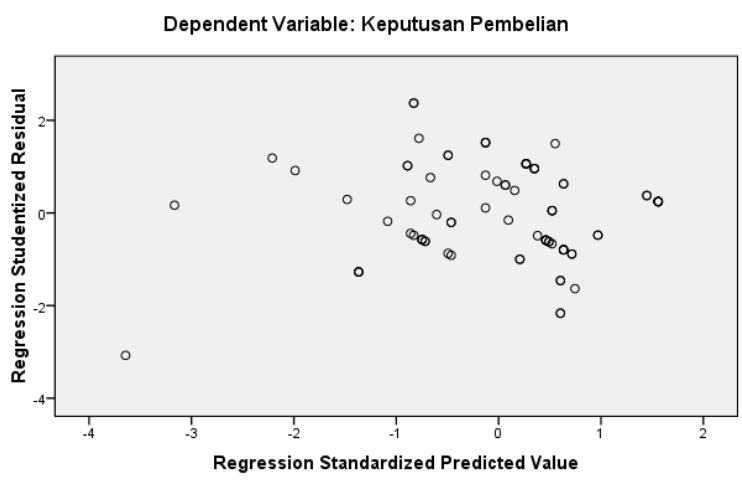

Gambar 2 Scatterplot Heteroskedatisitas

(Sumber : Diolah oleh penulis, 2021)

Gambar di atas, model regresi ditemukan non-diferensial karena data didistribusikan di wilayah antara 0 dan $\mathrm{Y}$ dan kita tahu bahwa tidak ada urutan tertentu. Data yang dikumpulkan tidak terjadi heteroskedastisitas, sehingga hasil analisis data terstandardisasi dapat digunakan untuk analisis.

\section{Uji Rergresi Berganda}

Pengaruh Kualitas Produk dan Electronic Word of Mouth terhadap Keputusan Pemelian

Tabel 7 Uji Analisis Regresi

\begin{tabular}{|c|c|c|c|c|c|}
\hline & $\begin{array}{r}\text { Unstan } \\
\text { Coeff } \\
\end{array}$ & $\begin{array}{l}\text { ardized } \\
\text { ients }\end{array}$ & $\begin{array}{c}\text { Standardized } \\
\text { Coefficients }\end{array}$ & & \\
\hline & $\overline{\mathrm{B}}$ & Ptd. Error & Beta & $\mathrm{T}$ & Sig. \\
\hline (Constant) & 25,964 & 1,114 & & 5,355 & $\overline{2,000}$ \\
\hline Kualitas Produk & , 187 & .066 &, 274 & 2,833 & ,006 \\
\hline Ewom & ,424 & .074 &, 551 & 5,697 & ,000 \\
\hline
\end{tabular}

(Sumber :Diolah peneliti, 2021)

$$
Y=5,964+0,187 X_{1}+0,424 X_{2}
$$

Keterangan :

Y : Keputusan Pembelian

$\mathrm{X}_{1} \quad$ : Kualitas Produk

$\mathrm{X}_{2} \quad$ : Electronic Word of Mouth

Interpretasi dari model regresi diatas yaitu :

1. Nilai konstanta pada penelitian ini sebesar 5,964. Artinya jika kualitas produk dan EWOM tidak berubah maka keputusan pembelian memiliki nilai 5,964.

2. Koefisien regresi Kualits Produk (X1) nilainya 0,187 artinya apabila variabel lain bernilai tetap dan Kualitas Produk (X1) terjadi peningkatan senilai 1 satuan,sehingga keputusan pembelian konsumen meningkat senilai 0,187. Nilai koefisien bertanda positif, maka 
adanya hubungan yang positif antara variabel Kualitas Produk terhadap Keputusan Pembelian. Jika kualitas produk meningkat, variabel keputusan pembelian meningkat.

3. Koefisien regresi E-WOM (X2) nilainya 0,424 artinya apabila variabel lain nilainya tetap dan Kualitas Produk (X1) mengalami penigkatan 1 satuan, maka keputusan pembelian konsumen akan meningkat senilai 0,424. Nilai koefisien bertanda positif, artinya adanyan hubungan yang positif antara variabel E-WOM terhadap keputusan pembelian. Jika EWOM meningkat, maka variabel keputusan pembelian meningkat.

Koefisien Determinasi $\left(\mathrm{R}^{2}\right)$ Kualitas Produk dan Electronic Word of Mouth terhadap Keputusan Pembelian

Tabel 8 Koefisien Determinasi $\left(\mathrm{R}^{2}\right)$

\begin{tabular}{lrrrr}
\hline \multicolumn{5}{c}{ Model Summary $^{\mathbf{b}}$} \\
\hline \hline Model & & \multicolumn{3}{c}{ Adjusted R } \\
\hline 1 & $\mathrm{R}$ & R Square & Square & Std. Error of the Estimate \\
\hline
\end{tabular}

(Sumber : Diolah oleh penulis, 2021)

Nilai Adjusted $R$ Square yaitu 0,573 atau 57,3\%. Kontribusi variabel independen kualitas produk dan $E$-WOM terhadap keputusan pembelian sebesar 57,3\%, sisanya 42,7\% dipengaruhi faktor lain.

\section{Uji Simultan Kualitas Produk dan Electronic Word of Mouth terhadap Keputusan Pembelian}

Tabel 9 Uji Signifikansi Simultan (Uji F)

\begin{tabular}{cccccc} 
Model & $\begin{array}{c}\text { Sum of } \\
\text { Squares }\end{array}$ & Df & Mean Square & F & Sig. \\
\hline \hline Regression & 233,700 & 2 & 116,850 & 57,373 & $.000^{\mathrm{a}}$ \\
Residual & 167,006 & 82 & 2,037 & & \\
Total & 400,706 & 84 & & & \\
\hline \hline
\end{tabular}

(Sumber : Diolah oleh penulis, 2021)

Nilai F hitung pada tabel diatas yaitu 57,373 $\geq 3,11 \mathrm{~F}$-tabel, tingkat signifikansi sebesar 0,000 $\leq 0,05$, dapat diartikan keputusan pembelian dipengaruhi signifikan oleh tiap variabel bebas secara simultan.

\section{Uji Parsial Kualitas Produk \& Electronic Word of Mouth terhadap Keputusan Pembelian}

1) Uji Parsial Kualitas Produk terhadap Keputusan Pembelian.

Kualitas produk memperoleh nilai signifikansi $0,000 \leq 0,05$, maka keputusan pembelian dipengaruhi secara parsial oleh kualitas produk.

2) Uji Parsial E-WOM Terhadap Keputusan Pembelian.

Nilai sig dari uji t $E$-WOM memiliki nilai $0,000 \leq 0,05$., maka keputusan pembelian dipengaruhi secara parsial oleh electronic word of mouth.

\section{Pengaruh Kualitas Produk terhadap Keputusan Pembelian}

Pada analisis diatas kualitas produk secara signifikan mempengaruhi keputusan pembelian. Kualitas produk bagi sebuah restoran merupakan inti. Restoran menciptakan produk yang berkualitas agar menarik serta membuktikan restoran tersebut kredibel terhadap bidangnya. Meningkatnya jumlah restoran, berarti semakin banyak nya tawaran yang diterima pada 
konumen potensial. Dengan begitu restoran harus lah mempunyai keunggulan tersendiri, salah satunya bisa dilakukan dengan kualitas produk yang terpimpin.

Menurut Kamaludin (2013), pengendalian kualitas produk merupakan semua usaha untuk menjamin hasil yang didapat memuaskan pelanggan. Kualitas produk yang terorganisasi menciptakan konsistensi rasa serta pengalaman antar konsumen dapat diukur. Lain hal jika kualitas tersebut tidak memiliki standar yang jelas, maka dapat dipastikan konsumen tidak akan mempercayai restoran sebab pengalaman yang diberikan selalu berubah dan akan menjadi hal yang negatif.

Kualitas produk memberikan sebuah nilai kepercayaan pada restoran, berasosiasi terhadap citra restoran tersebut. Sesuai dengan pernyataan tersebut Sulistiono (2013) kepercayaan terhadap perusahaan didapati melalui pengendalian kualitas produk sehingga konsumen selalu puas terhadap yang diberikan oleh perusahaan. Penting untuk selalu meningkatkan kualitas produk agar terjadi kepuasan dalam pembelian konsumen.

Maka hipotesis 1 "kualitas produk berpengaruh dan signifikan terhadap keputusan pembelian", dinyatakan diterima dan terbukti kebenarannya. Dody Ridwan Yunianto (2016), mengemukakan bahwa kualitas produk memiliki pengaruh yang signifikan dan positif terhadap keputusan pembelian

Yusra dan Nanda (2019) berpendapat bahwa kualitas produk berpengaruh secara parsial dan berpengaruh pada keputusan pembelian . seperti halnya yang dikemukakan oleh oleh Nugroho, dkk (2020) bahwa bahwa variabel kualitas produk memiliki pengaruh signifikan dan positif terhadap keputusan pembelian.

\section{Pengaruh Electronic Word of Mouth terhadap Keputusan Pembelian}

Didapati bahwa signifikan keputusan pembelian terpengaruh oleh E-WOM. Pengaruh tersebut bernilai positif maka electronic word of mouth penting untuk dilakukan secara efektif untuk meningkatkan penjualan.

Definisi E-WOM menurut Tomi Wijaya (2014) yaitu suatu komunikasi tentang suatu produk yang dilakukan antar konsumen. Kevindra (2020) menyatakan bahwa seseorang dapat menyukai makanan atau pun tidak disebabkan beberapa faktor, yaitu intrinsik dan juga ekstrinsik. Bagi konsumen mencari tahu secara detail mengenai produk, untuk memberikan rasa aman untuk membeli. Serta dimudahkan nya dengan konten mengenai makanan yang sering dibuat oleh pengulas makanan. Pencarian tersebut memberikan rasa kesenangan mengetahui produk yang akan dibeli di rekomendasi oleh orang lain pula sebaliknya jika makanan tidak di rekomendasi maka memberikan keamanan untuk tidak mencoba makanan tersebut.

Lebih lanjut mengenai pengulas makanan, pekerjaan tersebut memberikan informasi maupun secara tidak langsung mengarahkan pendapat calon konsumen. Dengan konten yang diberikan maka menciptakan keingintahuan konsumen terhadap makanan yg diulas. Kevindra (2020) menyatakan bahwa, tiap konsumen memiliki preferensi terhadap pengulas makanan yang berbeda, sebab tiap manusia memiliki kesukaan yang berbeda beda.

Maka sebaiknya dalam bidang industri restoran dapat mengambil hati pengulas makanan, tidak hanya menciptakan kesadaran terhadap produk kita melainkan hal poitif lainnya seperti umpan balik terhadap perbaikan produk makanan atau restoran.

Dengan begitu hipotesis 2 " $E-W O M$ berpengaruh dan signifikan terhadap keputusan pembelian", dinyatakan diterima dan terbukti kebenarannya. Djimantoro, dan Vania Clairine Gunawan (2020) membuktikan E-WOM berpengaruh seacara positif dan signifikan terhadap keputusan pembelian. Seperti halnya pendapat Santosa (2018) yang menyebutkan bahwa $E$ WOM berpengaruh secara positif dan signifikan terhadap keputusan pembelian. 


\section{Pengaruh Kualitas Produk dan Electronic Word of Mouth secara Simultan terhadap Keputusan Pembelian}

Kualitas produk dan $E$-WOM berpengaruh signifikan secara simultan pada variabel keputusan pembelian. Hasil analisis menunjukan keputusan pembelian dipengaruhi secara simultan oleh kualitas produk dan E-WOM sejumlah 57,3\% kontribusi sedangkan sisanya 42,7\% dipengaruhi variabel lainya.

Kualitas produk secara langsung terkait dengan E-WOM. Konsumen yang puas akan membahas kelebihan tentang produk tersebut, salah satunya kualitas produk. Kualitas produk yang baik memudahkan strategi komunikasi terhadap konsumen sehingga ewom yg terjadi positif. Dengan demikian "pengaruh kualitas produk dan dan E-WOM secara simultan terhadap keputusan pembelian", dinyatakan diterima dan terbukti. Wowor, dkk (2017) berpendapat bahwa Kualitas Produk dan E-WOM berpengaruh yang simultan terhadap Keputusan Pembelian.

\section{KESIMPULAN}

Kesimpulan penelitian ini yakni mengenai kualitas produk dan E-WOM pada Dimsum Mbeledos yaitu:

1. Secara parsial, kualitas Produk berpengaruh signifikan terhadap Keputusan Pembelian Dimsum Mbeledos Surabaya

2. Secara parsial, $E$-WOM berpengaruh signifikan terhadap Keputusan Pembelian Dimsum Mbledos Surabaya.

3. Secara simultan, kualitas Produk dan E-WOM mempengaruhi Keputusan Pembelian Dimsum Mbledos Surabaya.

\section{DAFTAR PUSTAKA}

Akbar, Muhamad J.C. \& Sunarti.2018. Pengaruh Electronic Word of Mouth terhadap Keputusan Pembelian (Survei Pada Konsumen Restoran Sushi Tei Kelapa Gading). Jurnal Administrasi Bisnis (JAB)|Vol. 60 No. 3 Juli.

Alma, Buchari. 2018. Manajemen Pemasaran dan Pemasaran Jasa. Bandung. Alfabeta. ISBN : 979-8433-01-7.

Aprilia. D. (2016). Pengaruh Kualitas Produk, Harga, Lokasi, Dan Kualitas Layanan Terhadap Keputusan Pembelian Di Djawi Lanbistro Coffee And Resto Surabaya. Surabaya.

Arikunto, S. 2010.Prosedur Penelitian Suatu Pendekatan Praktik. Jakarta: Rineka Cipta.

Assauri, Sofjan. 2011. Manajemen Pemasaran. Jakarta: Rajawali Pers.

Hair, Dkk. (2006). Multivariate Data Analysis Pearson International Edition Edition 6. New Jersey

Irvan, Syaivul. Dan Ade, Pungki. 2020. Beli Atau Tidak? Peran Electronic Word Of Mouth(Ewom) Dan Kepribadian Merek Terhadap Keputusan Pembelian. Jurnal Psikologi Sains Dan Profesi. Universitas Mercu Buana. Vol. 4, No. 2, Agustus 2020: 135 -14.

Jason, Djimantoro Dan Vania C. 2019. Pengaruh E-WOM, Kualitas Makanan Dan Kualitas Layanan Terhadap Keputusan Pembelian Di Rumah Makan Kakkk Ayam Geprek. Jurnal Manajemen Dan Kewirausahaan, Vol X, No. X. Universitas Kristen Petra.

Jie Chen, Lefa Teng. 2015. The Effect Of Online Information Sources On Purchase Intentions Between Consumerswith High And Low Susceptibility To Informational Influence. Journal Of Business Research Xxx (2015) Xxx-Xxx. Http://Dx.Doi.Org/10.1016/J.Jbusres.2015.05.003 
Kotler, Philip And Gary Armstrong. 2012. Prinsip-Prinsip Pemasaran. Edisi 12. Jilid 1. Terjemahan Bob Sabran. Jakarta: Erlangga.

Lucano, Gl Dan Devi K. 2018. Analisis Pengaruh Kualitas Produk, Promosi, Dan Interior Terhadap Keputusan Pembelian Konsumen Di Restoran Imperial Lamian Tunjungan Plaza Surabaya. Jurnal Manajemen Perhotelan Vol X No X. Universitas Kristen Petra.

Muzakar, Isa. 2019. Analisis Perilaku Konsumen Dalam Keputusan Pembelian Makanan Di Kota Surakarta. Jurnal Ekonomi Dan Bisnis. Universitas Muhammadiyah Surakarta.

Sulaeman, M. M. (2020). Sosialisasi Kewirausahaan dalam Upaya Peningkatan UMKM Desa Palangan Kecamatan Karangbinangun Kabupaten Lamongan. Jurnal Abdimas Berdaya: Jurnal Pembelajaran, Pemberdayaan dan Pengabdian Masyarakat,2 (01), 16-22.

Syairozi, M. I. (2021). analisis Kemiskinan di Sektor Pertanian (Studi Kasus Komoditas Padi di Kabupaten Malang). Media Ekonomi, 28(2), 113-128.

Tjiptono, Fandy, 2015. Strategi Pemasaran. Edisi 4: Andi Offset, Yogyakarta. ISBN: 978-97929-5349-7

Tommi Wijaya dan Eristia Lidia Paramita,Pengaruh Electronic Word Of Mouth (Ewom) Terhadap Keputusan Pembelian Kamera Dslr, Universitas Kristen Satya Wacana, Seminar Nasional Dan Call For Paper (Sancall 2014): Isbn: 978-60270429-1-9 Research Methods And Organizational Studies, hal 14.

Wijaya, K., \& Syairozi, M. I. (2020). Analisis perpindahan tenaga kerja informal Kabupaten Pasuruan. Jurnal Paradigma Ekonomika, 15(2), 173-182.

Wowor, Lingkan Theofhani. 2017. Analisis Pengaruh Strategi Harga, Kualitas Produk Dan Suasana Terhadap Keputusan Pembelian Pada Rumah Kopi Billy Megamas Manado. Jurnal EMBA Vol.5 No.3 September 2017, Hal.4115-4124. ISSN 2303-1174

Yunianto, Dody Ridwan. 2016. Analisis Pengaruh Kualitas Produk, Harga, Promosi Terhadap Keputusan Pembelian Di Rumah Makan Spesial Sambal Gonilan.

https://documentcloud.adobe.com/link/review?uri=urn:aaid:scds:US:d851aabc-d7b7-4d91acde-7f5862340186

Yusra, Irdha \& Nanda, Rio. 2019. Pengaruh Kualitas Produk, Lokasi dan Harga Terhadap Keputusan Pembelian Pada Cafe Kinol Bistro N'Poll Di Kota Padang. Jurnal Pundi, Vol. 03, No. 03, November. ISSN: 2556 - 2278. DOI:10.31575/jp.v3i3.173 